Perspectivas - Portuguese Journal of Political Science N. ${ }^{\circ} 8$, October 2012, 61-82 (c) NICPRI 2012

\title{
Away inside: emigrants and transnationalism through the eyes of political parties
}

Manuel Abrantes

Joana Azevedo

Ana Maria Belchior

Marco Lisi

Manuel Abrantes

Technical University of Lisbon, Research Centre in Economic and

Organizational Sociology (SOCIUS), Lisbon, Portugal

mabrantes@socius.iseg.utl.pt

Joana Azevedo

University Institute of Lisbon (ISCTE-IUL), Centre for Research and

Studies in Sociology (CIES-IUL), Lisbon, Portugal

joanaffazevedo@gmail.com

Ana Maria Belchior

University Institute of Lisbon (ISCTE-IUL), Centre for Research and

Studies in Sociology (CIES-IUL), Lisbon, Portugal

anamariabelchior@gmail.com

\section{Marco Lisi}

Universidade Nova de Lisboa,

Faculty of Social Sciences and Humanities

marcolisi@fcsh.unl.pt 
ABSTRACT

This article examines how political parties in Portugal organize concerning emigrants and the subject of migration outflow, uncovering the issues and strategies that they favour. The 2009 Portuguese legislative elections offer a privileged site for empirical inquiry. Not only are emigrants able to elect members of the national parliament through particular voting districts, but also a complete period of electoral campaigning under standard institutional conditions (rather than early elections) could thus be followed in real-time by the research team. Analysis draws chiefly on electoral manifestos, campaign activities, and first-hand interviews with members of the parliament and public officials. A close tie between the capacity of parties to organize abroad and the salience of issues related to the emigrant population

\section{Introduction}

During the last decade, increasing attention has been paid to the role of migrants in the political structure of their country of origin, in which they often retain representation rights by voting in national elections (Chelius, 2003; OstergaardNielsen, 2003; Barry, 2006; Fierro, Morales and Gratschew, 2007). The participation of migrants in home country politics is especially relevant as it encapsulates one of the pillars in emerging transnational citizenship, or, in other words, the redefinition of political agency in a world of intense global flows and new demands on the performance of democracy (Itzigsohn, 2000; Bauböck, 2003; Sassen, 2007; Lafleur and Martiniello, 2009).

This debate still lacks a thorough understanding of the actual contexts and factors under which migrants practice their rights. In particular, research has neglected how key actors in the operation of contemporary democratic systems such as political parties conceive and organize vis-à-vis nationals residing abroad. At the same time, the severe economic recession in Europe underlies the reassertion of migration outflows as a public issue rather than a private matter concerning only a minority of citizens. As shown below, the Portuguese legislative elections in 2009 offer a privileged site to observe arguments, strategies and priorities favoured by parties on this subject. This case deserves special attention considering the massive number of Portuguese citizens residing abroad and their extensive voting rights which are nonetheless pervaded by practical limitations and difficulties (Malheiros and Boavida, 2003; Lobo, 2007).

A critical review of literature will be followed by empirical examination based on party manifestos, campaign activities, and first-hand interviews with members of the national parliament and public officials. Press coverage and transcripts of parliamentary sessions provide complementary data. Findings expose a close tie between the capacity of parties to organize abroad and the salience of issues related to the emigrant population in their programs. It is argued that the ambiguous position of external voting between the strengthening of national(istic) bonds and transnational citizenship is disputed within the party system, since attitudes towards each of the two perspectives vary across parties. ${ }^{1}$

\section{Emigrants, elections, and political parties}

Growing cross-border migration and particular concerns with the performance of contemporary democracy have promoted interest in the political participation 
of migrants. According to Rainer Bauböck (2003), a key task is to examine transnational phenomena, that is, those involving overlapping affiliations of people to geographically separated polities. The novel development may be found less in the political orientation of migrants than in the opportunities that they have to articulate statuses and affiliations. Voting in home country elections holds a key position in this debate, together with the interwoven issue of cumulative nationalities. On the one hand, this is based on the practical and symbolic centrality of voting in western democracies. On the other, the vote of emigrants poses a particular normative challenge. While it contributes to weaken the traditional notion of political belonging as territorially bounded and mutually exclusive, it also reaffirms the importance of national memberships (Rubio-Marín, 2006).

Voting from abroad - or external voting - is currently permitted in the law of most countries in all continents of the world (Fierro, Morales and Gratschew, 2007). It is remarkable that the first nations implementing it compose a quite heterogeneous group in regard to the political regime in place, the volume of nationals residing abroad, or geographic location (Blais, Massicotte and Yoshinaka, 2001; Chelius, 2003; Ellis, 2007). ${ }^{2}$ Recent research also shows that external voting in many countries is confronted with significant formal restrictions and practical limitations, exposing the difficulty or delay of political-administrative systems in ensuring this ambitious enterprise to its full extent (Thompson, 2003; Spiro, 2006). As claimed by Dieter Nohlen and Florian Grotz (2000), it is necessary to consider not only legal aspects but also political issues related with the logistics and organization of elections (political-procedural issues) and with party strategies and the dynamics of the party system (political-institutional aspects). Research in Latin American countries with vast migration outflows further shows that the driving forces in the institutionalization of transnational politics can be found in state apparatus, migrant organizations in the receiving country, or political parties in the sending country (Itzigsohn, 2000; López-Guerra, 2005). Whereas the former two may favour the development of new forms of representation, political parties are expected to channel their efforts into conventional forms of participation such as voting in national elections. In a context of economic recession, considerations on individual mobility and money remmittances are important in the turn of emigrants from 'lost citizens' into heroic figures in public discourse (Barry, 2006).

According to data from various sources, the number of Portuguese nationals residing abroad is estimated at 2,3 millions, and it reaches as high as 5 millions once their offspring are included (Pires et al., 2010). Traditional countries of in party programs is exposed. It is argued that the ambiguous position of externa voting between the strengthening of national(istic) bonds and transnational citizenship is disputed within the party system, since attitudes towards each of these perspectives vary acros parties. Parties must therefore be understood as key players in the ongoing redefinition of the political agency of migrants, bearing a significant impact on their participation and representation. Last, implications for future research are addressed.

KEYWORDS

Elections; emigrants migration; political parties; transnationalism 
destination such as France, Germany and Luxembourg, in Europe, or Brazil, Venezuela, United States and Canada, in America, remain significant. New thrusts over the last two decades have changed the profile of emigrants towards greater diversity in their educational skills, family structure and mobility patterns, as well as a growing relevance of Spain, Switzerland, United Kingdom, Angola and Brazil as receiving countries (Peixoto, 2004, 2007). Unlike other countries in Europe, outflows in Portugal have been remarkably persistent over the last decades, even in periods of economic growth. Interestingly, by the time of the 2009 legislative elections the issue of increasing emigration as a consequence of recession was not as strongly perceived in public debate as it would become soon afterwards.

Participation in legislative elections through postal voting is allowed since $1975 .^{3}$ Nationals residing abroad are able to vote through two extraterritorial electoral districts: 'Europe' and 'Outside Europe'. However, the principle of proportionality regulating the relationship between resident population and parliament seats in incountry districts does not apply to the extraterritorial ones. From this viewpoint, the external vote in Portugal can be considered an example of malapportionment given the bias in its representation at the national level. By electing only two members of the parliament each (four seats in total), these are the smallest districts compared with the in-country ones, and their high level of disproportionality means that it is extremely difficult for smaller political parties to elect representatives (Martins, 2004). The choice of such configuration may be explained by the concern that the massive number of Portuguese emigrants would be in a position to elect a large share of the members of parliament, and that this would be unfair since emigrant voters do not live in the home country (Lobo, 2007: 83-84).

The extension of voting rights and the substantial and still growing number of emigrants contrast sharply with their low and decreasing turnout in elections (Malheiros and Boavida, 2003; Lobo, 2007). By the 2009 legislative elections, the total number of individuals registered to vote abroad stood at 167,007 thousands (72,536 in Europe, and 94,471 outside Europe), and only 15,3 percent of this population actually voted. In fact, turnout among emigrants shows the same exponential decline since the mid-1980s as national turnout at large, although this decline has been faster and more severe among emigrants (Freire and Magalhães, 2002; Martins, 2004; Azevedo et al., 2012). Certainly various dimensions of political integration are relevant in accounting for turnout. ${ }^{4}$ Low turnout rates suggest that the inclusion of emigrants in national politics is still - and perhaps increasingly - far from substantiation. 
A thorough description of the party system in Portugal can not be undertaken here (important references are Lobo, 1996; Freire, 2005; Jalali, 2007). However, a number of key characteristics must be outlined to frame the ensuing analysis. The two most voted parties in Portugal, the Socialist Party (Partido Socialista, or PS, centre-left) and the Social-Democratic Party (Partido Social-Democrata, or PSD, centre-right), have alternated in power since the establishment of the multi-party system in 1974 with either single-party or coalition governments. The latter have been often formed in alliance with the right-wing party Social Democratic Centre - Popular Party (Centro Democrático Social - Popular Party, or CDS-PP). On the left, there are the Portuguese Communist Party (Partido Comunista Português, PCP), the party with the longest tradition and strongest roots in Portugal (Jalali, 2007); and the Left Bloc (Bloco de Esquerda, BE), a venture of various small leftwing forces that gathered to found a new party in 1999.

While fluctuation in party choice abroad has been generally consonant with the overall results of elections at the national level, a party or ideological cleavage between the two emigrant districts is apparent. A diachronic analysis covering the period of 1974-2009 shows that the PSD has systematically obtained better results outside Europe; in contrast, the distribution of votes and parliament seats in the district of Europe has been disputed between this party and the PS (Azevedo et al., 2012). The political signalling of emigrant communities by the PSD, especially in the periods of the 1980s and 1990s during which this party was in office, can not be detached from the regular election of a majority of deputies in the emigrant districts (Santos, 2004; Lobo, 2007). Another notable feature is that the CDS-PP has consistently attained a better result than the PCP, even when the reverse happened at the national level. In addition, the CDS-PP maintains a much stronger support outside Europe, while votes for the PCP are concentrated in Europe. The BE also gathered a growing number of votes in Europe until 2009 although its significance is still very reduced. A pattern that emerges clearly from the longitudinal assessment is the alignment of emigrant constituencies within the traditional left-right continuum, with a preference towards the right outside Europe and a preference towards the left in Europe, especially since the 1990s (Malheiros e Boavida, 2003; Azevedo et al., 2012). This is especially remarkable considering that Portugal has been identified in comparative perspective for its high electoral volality (Gunther, 2004), low party loyalty (Lobo, 1996: 1086), and widespread fluctuation among voters in the central segment of the ideological spectrum (Jalali, 2004; 2007). 
Research on the political participation of migrants has been mainly concerned with regulations and individual behaviour (Marcelli and Cornelius, 2005). In contrast, the role and dynamics of political parties are less often examined in a critical or detailed manner, even though their prominence has been acknowledged (Barry, 2006; Lafleur, 2012). While contemporary parties may be considered to be in decline or transformation, their behaviour is key to illuminate both past developments and future prospects regarding democracy (Dalton and Wattenberg, 2000; Laver, Benoit and Garry, 2003; Freire, 2009). On the other hand, research on voting behaviour to date shows a notable preference for longitudinal analysis. Whereas historical processes have been very usefully described, issues of context - in particular those concerning the party system and the political cycle - remain in the penumbra.

The question with which this article is concerned is how political parties in Portugal organize regarding emigrants and the subject of migration outflow in a period of electoral campaign. The aim of examining arguments, strategies and priorities favoured by political parties is threefold. First, it contributes to the debate on transnational citizenship and the performance of contemporary democracy. Second, emigrants are perceived by political parties at two distinct levels: they are both a constituency (voters, agents) and a political issue (subject). Therefore, party action and discourse at these two levels is bound to affect the public construction and everyday experience of emigrants. Last, a better understanding of this particular field of political action informs the wider debate on parties and their operation in a context of declining turnout. It is important to bear in mind that alternative forms of political participation are just as important. This is the case of voting at local elections in the country of destination. It is also the case of non-governmental actors such as the Council of the Portuguese Communities or immigrant associations. In sum, the political participation of emigrants comprises several channels or dimensions, a variegated landscape in which political parties nonetheless seem to maintain a key role.

\section{Methodological considerations}

Elections are a privileged site to observe party behaviour (Laver, Benoit and Garry, 2003: 311). The selection of the 2009 Portuguese legislative elections as a case study is based on three reasons. First of all, legislative elections hold unique characteristics in regard to mobilizing voters. They are first-order elections, a 
phrase coined to underline their greater impact on the control of executive power comparing to the elections of the European Parliament or presidential elections in non-presidentialist systems (Reif and Schmitt, 1980; Freire, 2005; Nunes, 2005). Second, Portuguese emigrants are entitled to elect 'their own' representatives in national parliament. Third, there are considerable methodological benefits in following the electoral campaign in real-time. Furthermore, the 2009 elections were organized upon completion of a regular four-year parliamentary mandate - indeed the only occasion that this happened in the $21^{\text {st }}$ century in Portugal so far, despite the trend towards governance stability since the mid-1980s (Lobo, 1996). This circumstance offers standard conditions for electoral campaign, which is less likely to be the case in early elections.

Formal documents published by parties during the electoral campaign are a key source of information. To be sure, doubts arise as to their accuracy in expressing the positions of parties, especially considering that the relation between propositions presented before elections and policies pursued after elections remains obscure to both voters and scholars (Caul and Gray, 2000: 235). Reluctance dissolves under the evidence that ascertaining the 'real' position of a political actor is a 'fundamentally elusive, even metaphysical, notion' (Laver and Garry, 2000: 620). Party manifestos are precious as they remain available for observation regardless of any eventual change in strategy or interpretation by party representatives (Laver, Benoit and Garry, 2003: 311).

A further issue is how to examine party propositions in a systematic and accurate manner. Distinguishing between 'valence issues' and 'position issues' is useful in this regard (Budge et al., 2001). According to this typology, valence issues are goals shared by most of the political competitors, although there may be disagreement concerning the adequate means to achieve them. In contrast, position issues are policies that divide political parties in a more substantial manner as they take completely different stances on the goals to be achieved. Theory on issue ownership further expects parties to attract voters by emphasizing issues on which they have a reputation of competence. ${ }^{5}$ Despite the generalized notion that politicians are motivated by a normative rejection of statements or actions from their rivals, empirical research suggests that debate develops chiefly through the emphasis on distinct priorities (Budge et al., 2001: 6-7). In this view, it is not only the position of parties on a given subject that matters, but also the salience that they grant to it (Laver and Garry, 2000). ${ }^{6}$ 
Such content analysis requires confrontation with other sources of evidence. ${ }^{7}$ Legislation, press coverage, and transcripts of parliamentary debates from September 2008 to December 2009 were therefore incorporated in the analysis. In addition, semi-structured interviews with members of the parliament were conducted between September 2009 and March 2010; during the same period, regular consultation with public officials allowed the clarification of relevant technical and political procedures. ${ }^{8}$

The empirical material examined in this article is certainly far from exhausting the debate. In particular, a systematic survey of legislation within a longer time frame would offer a clearer view into the correspondence between propositions included in electoral manifestos and measures implemented in each legislature. Other implications and recommendations for further research are mentioned in the concluding section.

\section{The 2009 legislative elections: party manifestos and campaign activities}

Three elections occurred in Portugal during 2009: european elections in June, legislative elections in September, and local elections in October. Legislative elections followed a four-year government of the PS with a majority of 121 (in 230) seats in parliament. The number of competing parties in 2009 was larger than ever since 1976 (Espírito Santo, 2010). To understand the context in which elections were disputed, it is important to add that the preceding legislature comprised significant reforms in administration and regulation, some of which met with fierce opposition from social partners and other political actors. Under further pressure of the financial crisis, the PS suffered a steep decline in popularity (Lisi, 2010: 382). The global reorganization of consular services led by the government since 2007 resulted in the opening of new units in some countries and the closing in others; migrant organizations conducted demonstrations in Lisbon and several cities of France. ${ }^{9}$ This mobilization was eventually interwoven with the two strikes called in 2009 by the Union of Workers of Consulates and Diplomatic Missions (STCDE). Pleading against the postponement of wage updates, revisions in their professional regulation and the new system to assess the performance of officials, both strikes were carried out a few days before european and legislative elections respectively. ${ }^{10}$

On the other hand, the overwhelming election of the candidate supported by the PSD and the CDS-PP in the presidential elections of 2006 and the substantial 
victory of the PSD in the 2009 European elections confronted the government with political resistance at various levels. This was the case when the President of the Republic vetoed the Law-Project 562/X, according to which postal voting for emigrants in legislative elections would be replaced by personal voting (Azevedo et al., 2012: 71-6). Approved in parliament with the votes of the PS and the PCP, the law was nevertheless rejected by the President of the Republic after the public intervention of various migrant representatives against it. ${ }^{11}$

While the aim of this study is to cover a particular area of political intervention, it is important to bear in mind that areas of intervention in party manifestos are to a certain extent inextricable. For instance, the electoral manifesto of the PSD begins by approaching five topics presented as 'Our Priorities'; these are followed by a considerable number of other topics, in which the section entitled 'Portuguese Communities' is included. It is also significant that the party favoured a short and easy-to-read manifesto comparing both to its manifestos in earlier elections and to other party manifestos in 2009. The section on 'Portuguese Communities' is a clear expression of this orientation, and since most of its propositions concern issues that the party considers relevant to emigrants in particular they are not approached in the remainder of the manifesto. The content of any manifesto is the result of these multiple negotiation levels and choices regarding the overall balance of subjects (Budge et al., 2001: 7).

The first measurement of salience is based on the quantification of propositions and pages in the manifestos considering the total dimension of documents (see note 6 for key methodological references). In this view, the parties represented in parliament that grant more salience to the emigrant population are the PS, the PSD and the CDS-PP. This attention is more reduced in the manifesto of the PCP, and it is almost inexistent in the manifesto of the BE. Emigrants are also mentioned in the electoral manifesto of some parties which are not represented in parliament. The New Democracy Party (Partido da Nova Democracia, PND) in particular grants them a privileged position. In fact, the formation of some of the smallest parties is closely related to the subject of migration. Created in 2003 by dissenters of the CDS-PP, the PND presented since then a set of key moral and cultural challenges with an emphasis on patriotism and national identity (see Partido da Nova Democracia, 2003). The Democratic Party of the Atlantic (Partido Democrático do Atlântico, PDA), formed in the Azores in 1979, pays particular attention to the situation of Azorean emigrants in Canada and the United States. Indeed, the historical record of migration outflow from the archipelagos of Madeira 
and Azores is a piece of key explanatory value to understand the emergence of regionalist nuances in discourses and initiatives regarding the Portuguese diaspora (Vicente, 1999; Pires et al., 2010).

The electoral manifestos in which a larger segment of the text is dedicated to emigrants - through particular chapters and a numerous list of policy propositions - also show a greater importance attached to nationality as a political and social tie. This is especially the case in the parties associated with the parliamentary right (PSD, CDS-PP, PND). In the manifestos of the parties associated with the parliamentary left (PS, PCP), the rights of emigrants within the Portuguese political system are often interwoven with their rights in the countries where they currently reside; the latter are sometimes looked upon as more important. It is also common for these parties to establish a link between the experience of Portugese citizens abroad and the experience of immigrants in Portugal, which is not to be found among right wing parties. This distinction has been corroborated in the interviews conducted with members of the parliament, as testified in the following excerpts.

I believe another component is important, and that is integration: the participation of Portuguese migrants - including at the local level, right?, but not only - in the receiving countries. I believe it is important that emigrant communities... for their own defense... that they have an adequate political and civic insertion in the countries where they are, which is not incompatible with maintaining their national identity whatsoever... the fact that they try to integrate also in the countries where they are and participate there. I believe that like it is defensible for us that immigrants, that is, foreign citizens residing in Portugal have more possibilities of political participation in Portugal, it also seems important to us that Portuguese migrants have possibilities to participate politically where they are, and not only in relation to Portugal, where the impact of their participation is relatively small, right? [Interview PCP]

Very often we also seek collaborative action by inviting representatives of the parties - the French Socialist Party in France, the PvDA in the Netherlands, or the SPD in Germany, or the Labour in England - to be present and cooperate so that there is a closer relation between our communities and decision-making institutions in the receiving countries. And this is also an important part of our activity and our support. [...] So, the socialists eventually move nearer to their 'brother' parties for mutual benefit; so that they can have the support of those parties in their initiatives, and in exchange our communities are more encouraged to participate in the local life. When there are local elections, for instance municipal elections, the participation of the community is always a very positive thing, not only because it shows 
integration and participation in the decisions that concern them but it has also got a return, which is the recognition that Portugese emigrants eventually earn for their political participation, for their civic engagement. And therefore we also try to promote that connection. [Interview PS]

Both of these approaches suggest that party delegates are often more concerned with the nexus of migration and political participation at large than with shortterm electoral gains, especially since their chances of electing a member of the parliament is reduced. At the same time, such priority can be instrumental to expand cooperation with fellow parties in destination countries, which are also interested in reaching out to local immigrant communities. As suggested by recent research in other countries, joint political actions of this sort are expected to yield a win-win situation considering that immigrant communities comprise individuals who hold voting rights in the origin country, the destination country, or both (Lafleur, 2012; Tintori, 2012).

The case of the BE, the only party represented in parliament that did not include a specific section dedicated to emigrants in the electoral manifesto, is also notable. Overall, the manifesto of the BE is the least inclined to address segments of the population in particular terms (agricultoral workers, entrepreneurs, the unemployed, etc.). The member of the parliament interviewed identified this as an indicator of a more inclusive and egalitarian perspective regarding emigrants.

We took people out there exactly the same political propositions we presented here. And I'll tell you: I think this was an advantage. We did not go there with the stereotypical issues of emigrants. Certainly we must address their concrete situation, but one must also consider that the national parliament is being elected. [Interview BE]

Concerning the actual content of policy propositions on this subject, the significan number of coinciding statements across parties confirms expectations based on the reviewed literature (Dalton and Wattenberg, 2000; Budge et al., 2001). This is the case of the modernization of consular services, a measure defended with almost identical words by PS, PSD and PCP. It is also the case of investing in the diffusion of Portuguese language and culture, a proposition presented by PS, PSD, PCP and CDS-PP. Last, it is also the case of establishing partnerships between national entrepreuners in Portugal and abroad in order to increase economic competitiveness (PS, PSD and CDS-PP). Perhaps surprisingly, the sharing of these propositions was confirmed, one by one, in the interviews with members of the parliament. A larger number of propositions is shared by parties that collaborate often in parliament. This 
happens especially among right wing parties. The clearest examples are incentives for highly qualified Portuguese citizens to return or to stay in national territory (PSD and CDS-PP) and the extension of Portuguese nationality to third generation migrants (PSD and PND).

Very similar statements do not necessarily imply agreement. On the one hand, it has been commented that parties compete through position issues, as well as the emphasis that they give them. On the other, even a shared goal may comprise difference in the strategies promoted to accomplish it. One could think for instance of the modernization of consular services or the diffusion of Portuguese language and culture. As to the concrete means to pursue such goals, the examined electoral manifestos are unanimously elliptic. ${ }^{12}$

Examination identifies three key thematic domains in which propositions regarding emigrants are presented: economic and social policy, culture and local associations, and the relation between citizens and state institutions. The distribution of propositions across these three domains varies significantly across parties. The propositions of the PS are concentrated in the former two, whereas the propositions of the PSD are concentrated in the first and the third ones. The convergence of the PSD's propositions in the domain of the relation between citizens and state institutions is a natural extension of the criticisms raised by this party in the period of 2005-9 concerning the direction of consular and diplomatic issues by the government of the PS. The remaining parties also express criticisms to the action of the government, although in a less particular or concrete manner. The propositions they present are in fact distributed across the three key domains in a more equitative manner. Last, parties unrepresented in parliament focus on one key domain only. The most remarkable case is the PND, which includes a solid assortment of propositions for the consolidation and support of the diaspora, similarly to what had already happened in their first appearance in legislative elections in 2005.

Campaign activities introduce interesting evidence. It is important to note that visual campaign abroad is restricted to sending documentation directly to voters through post. ${ }^{13}$ Political parties may require a copy of the personal addresses of emigrant voters from the Ministry of Foreign Affairs; correspondence with voters remains at the party's expenses. One further singularity of campaigning abroad is that parties generally try to establish strategic bonds with migrant organizations and other Portuguese groups in regions where a large number of voters live. These 
organizations can exert a significant influence on the relation between voters and the political system. The support of parties from receiving countries can also be sought through formal or informal alliances. In addition, parties that are in office in Portugal are to a certain extent able to approach emigrants within official visits from representatives to the main countries of destination, a strategy confirmed in our fieldwork interviews and press analysis.

The same sources of evidence also show that the PSD and the PCP were the most prolific parties in regard to the volume of campaign activities. The campaign of the PCP comprised visits from the candidates to regions with a large number of Portuguese residents for rallies and debates. A further action was conducted in national territory during the month of August to attract the attention of emigrants who were then in Portugal for holidays. The campaign activities of the PSD were also led by its candidates in the emigrant districts, with the remarkable difference that three of them were already members of the parliament in 2005-9. The three would be reelected in 2009; in fact, one of them has been elected for ten times in a row, having competed until 2002 for a national district. This sequence of events led one of the members of parliament to comment after the elections:

We win elections - we won the last two elections outside Europe with very significant results, we have the total number of deputies at stake - this has a lot to do with the personal relationship, you see? People who vote for us do not vote for the PSD, they vote for us because they know us. There are cases in which they vote because of the party, I won't say it doesn't happen, but not for the majority; the majority has a personal identification. In Europe it is a little bit different. Because in Europe there is a greater closeness to Portugal, greater, I won't say in all countries, but overall, people come here regularly, they follow things much more - with much more attention - for example the media, information in general, and therefore their relationship is much more direct. And then you can say that the vote is more based on the party, of course it is. [...] In the end, these two districts follow a logic that is almost uninominal already, you see? Although two seats are at stake - but there is a very direct logic, a very direct relation between the voter and the elected. [Interview PSD]

The campaign activity conducted by the PSD candidates was reinforced by the attention that the party leader, Manuela Ferreira Leite, devoted to emigrants in various strategic moments: early in the period when the electoral manifesto was under preparation, with a personal visit to Paris to gather the concerns of emigrants; later, meeting in Lisbon with prominent members of the Portuguese communities 


\begin{abstract}
abroad as she made the first public presentation of the party propositions regarding emigration; and, last, when she met with highly qualified Portuguese youth working abroad and affirmed her concern regarding the departure of talented workers and the absence of a political response to the problem to date. ${ }^{14}$ Still considering the role of candidates in campaign activites, it is noteworthy that the only member of the parliament elected for the PS in the electoral districts abroad in 2005 did not run in 2009 again. The leader of the PS participated in a rally in Paris with the candidates for the district of Europe. In the case of the BE, the electoral campaign targeting emigrants was minimal, promoted only in Europe by the members of the party elected for the European Parliament three months earlier. While some of the parties were unsurprisingly engaged in magnifying their activities through media coverage and internet communication technology, the final perception is that such effort has not been able to translate into a wishful increase in turnout so far.
\end{abstract}

Campaign activities were carried out especially in Paris, Brussels, and some cities of Brasil, in particular São Paulo. Despite the sharp regional difference in the electoral choice of Portuguese emigrants (see above), this is not reflected on the geographic distribution of campaign activities undertaken by each party. On the contrary, the work of parties in the electoral period of 2009 was intensely concentrated in the three mentioned cities, with some smaller initiatives in other towns of the same countries, as well as Luxembourg and Germany. To be sure, these are regions where a large number of Portuguese nationals live and electoral turnout has been higher than in other receiving countries (Azevedo et al., 2012). However, the campaign activities of parties in each particular country does not translate clearly into the number of votes that they obtain there.

The volume of campaign activities across parties is also linked to historical and organizational aspects. In the cases of the PCP and the PS, groups of party members abroad formed in the period of the authoritarian regime. They were especially active in France, Belgium, and Luxembourg. While many of the political activists returned to Portugal after 1974, some of them collaborated in the creation or continuity of working groups in their lands of exile. Differently, the presence of the PSD and the CDS-PP abroad suffered the major thrust in the years following 1974 and it developed chiefly outside Europe, in countries such as the United States, Canada, South Africa and Brasil, where competition from left wing parties was always small. ${ }^{15}$ On the other hand, the PSD and the PCP have been able to maintain robust practices of representation and communication between the core party structure in Portugal and their working groups abroad. Plus, the PCP working groups in some countries such as Germany are engaged in the mobili- 
zation efforts of local trade unions. These channels permit not only regular and complete sharing of information, but also a more consolidated presence of claims emerging from the emigrant population in the programmatic orientations of the party. In both parties, the propositions presented in the 2009 electoral campaign were discussed a priori - instead of a posteriori - with the party members abroad, which is expected to grant them additional opportunities to contribute to the final outcome.

\section{Conclusion}

The underlying claim at the outset of this article was that migrating can not be understood as meaning the loss of political agency without a reassessment of the performance of contemporary democracy. Analysis focused on a relatively unknown dimension of such agency, the participation in home country elections, arguing that the key role of political parties in this channel of transnational citizenship has been underestimated in previous research (Itzigsohn, 2000; Barry, 2006). Depending on the enfranchisment rules of electoral systems, emigrants can be as much away from the territory of their origin country as inside its political system. This is the case of Portugal. The examination of empirical material above seeks to illuminate how political parties in this country organize concerning emigrants and the subject of migration outflow in a context of electoral campaign, exposing the issues and strategies that they favour.

Two distinct explanatory levels emerge to answer this question. The first of them is mainly relational, that is, it pertains to inter-party dynamics. In this regard, the case of the 2009 Portuguese legislative elections confirms the theory on issue ownership (Budge et al., 2001; Bélanger and Meguid, 2008). The main suggestion from the fieldwork interviews is that there has been an appropriation of the subject of emigrants by one of the political parties, the PSD; this appropriation is based on a historical process of three decades and lends this party considerable power in defining priority issues for debate and even the language to be used. More recently, the PS has been able to reduce this unbalance. This helps understand the coincidence of a substantial number of valence issues across parties, although cohesion is clearer among right wing parties. It also exposes the importance of paying attention to the salience of this particular subject in electoral manifestos as an indicator of party positioning. On the one hand, more or less salience can be explained by the centrality or marginalization of the issue in the agenda of the 
party; on the other hand, it uncovers key differences in ideological orientation. Whereas parties associated with the right half of the parliament give emphasis to nationality and base their discourse on the notion of mutually exclusive sovereignties, parties from the other half of the parliament approach the subject chiefly through the lens of migration and mobility. The ambiguous position of external voting between the reinforcement of national bonds and the emergence of transnational citizenship (Bauböck, 2003; Rubio-Marín, 2006) is thereby disputed between political parties, which demonstrate different attitudes towards each of these two perspectives.

Secondly, the examination undertaken also shows that the greater or lesser salience of issues related to the emigrant population in party programs is related to their capacity to organize abroad. Two implications for future research are worth mentioning. One of them is that the geography of political transnationalism can be characterized by severe asymmetry. It is impressive that party action is intensely concentrated in a small number of places, some of which can be labelled global cities (Sassen, 2007). This small number contrasts strikingly with evidence on the dispersion of Portuguese migrants across about 140 world countries, and the growing significance of destination countries such as Angola or the United Kingdom has not translated into significant electoral participation so far (Pires et al., 2010). This corroborates the expectation that political parties mobilize mainly in the regions that already register a higher electoral turnout. However, a clear geographic distribution of parties across the regions where each of them obtains a larger number of votes is not to be found. The costs associated with the organization of initiatives abroad, the shortage of militancy or human resources, and the little benefit in votes amplify dramatically the isolation of regions where party presence is less robust, and emigrant voters will tend to remain less informed. A challenging alternative hypothesis is that party presence does not influence the level of information among emigrant voters.

A detailed assessment of historical elements and internal party dynamics lies beyond the scope of this article. It does however emerge as a necessary step to undertake in future research. An important hypothesis to examine is whether the wealth of valence issues and the scarcity of position issues reflect a progressive weakening of this subject in emigrant politics. Modernizing the consular services and investing in the diffusion of Portuguese language and culture, key issues as they were during the legislature of $2005-9$ and the electoral campaign that followed, hold a privileged position in political debate since at least the mid- 
1980s (Aguiar, 1987; Vicente, 1999). Another relevant contribution of diachronic research would be to clarify the relation between party behaviour concerning migration and the ideological and organizational transformation that they have been through themselves. On the other hand, it is remarkable that - either in electoral manifestos, parliamentary debates, or the interviews conducted in the fieldwork - issues concerning emigrants have recurrently come up within debate on different subjects. Examples are the economic recession and rising domestic unemployment, electoral turnout and the need to improve democracy mechanis$\mathrm{ms}$, regional asymmetry in resources and local policy, or immigration and ethnic diversity in Portuguese territory. These subjects are likely to be vehicles for the growing visibility of emigrants in the discourse and action of political parties in the near future.

\section{References}

Aguiar, Manuela. 1987. Política de Emigração e Comunidades Portuguesas. Porto: Secretaria de Estado das Comunidades Portuguesas.

Azevedo, Joana, Ana Maria Belchior, Marco Lisi and Manuel Abrantes. 2012. Votar no estrangeiro: Participação política e cidadania dos emigrantes portugueses. Lisbon: Research Report, CIES-IUL.

Barry, Kim. 2006. Home and away: The construction of citizenship in an emigration context. New York University Law Review 81: 11-59.

Bauböck, Rainer. 2003. Towards a political theory of migrant transnationalism. International Migration Review 37: 700-723.

Bélanger, Éric and Bonnie M. Meguid. 2008. Issue salience, issue ownership, and issuebased vote choice. Electoral Studies 27: 477-491.

Blais, André, Louis Massicotte and Antoine Yoshinaka. 2001. Deciding who has the right to vote: A comparative analysis of election laws. Electoral Studies 20: 41-62.

Bobbio, Norberto. 1995. Il futuro della democrazia. Turin: Einaudi.

Budge, Ian, Hans-Dieter Klingemann, Andrea Volkens, Judith Bara, and Eric Tanenbaum. 2001. Mapping policy preferences. Estimates for parties, electors, and governments 1945 1998. Oxford: Oxford University Press.

Caul, Miki L., and Mark M. Gray. 2000. From platform declarations to policy outcomes Changing party profiles and partisan influence over policy. In Parties without partisans. Political change in advanced industrial democracies, ed. Russell J. Dalton and Martin Wattenberg, 208-237. Oxford: Oxford University Press

Chelius, Leticia Calderón, ed. 2003. Votar en la distancia: La extensión de los derechos políticos a migrantes, experiencias comparadas. Mexico: Instituto Mora. 
Dalton, Russell J., and Martin Wattenberg, eds. 2000. Parties without partisans. Political change in advanced industrial democracies. Oxford: Oxford University Press.

Ellis, Andrew. 2007. The history and politics of external voting. In Voting from abroad: The international IDEA handbook, AA. VV., 41-8. Stockholm: Trydells Tryckeri AB.

Espírito Santo, Paula. 2010. The 2009 Portuguese parliamentary elections. Electoral Studies 29: 276-296.

Fierro, Carlos Navarro, Isabel Morales, and Maria Gratschew. 2007. External voting: A comparative overview. In Voting from abroad: the international IDEA handbook, AA. VV. 11-34. Stockholm: Trydells Tryckeri AB.

Freire, André. 2005. Eleições de segunda ordem e ciclos eleitorais no Portugal democrático, 1975-2004. Análise Social XL, 177: 815-846.

Freire, André. 2009. Reformas eleitorais: Objectivos, soluções, efeitos prováveis e tradeoffs necessários. Eleições 12: 25-60.

Freire, André, and Pedro Magalhães. 2002. A abstenção eleitoral em Portugal. Lisbon: Imprensa de Ciências Sociais.

Gunther, Richard. 2004. As eleições portuguesas em perspectiva comparada: Partidos e comportamento eleitoral na Europa do Sul. In Portugal a votos: As eleições legislativas de 2002, ed. André Freire, Marina C. Lobo, and Pedro Magalhães, 35-85. Lisbon: Imprensa de Ciências Sociais.

Itzigsohn, José. 2000. Immigration and the boundaries of citizenship: The institutions of immigrants' political transnationalism. International Migration Review 34: 1126-1154.

Jalali, Carlos. 2004. As mesmas clivagens de sempre? Velhas clivagens e novos valores no comportamento eleitoral português. In Portugal a votos: As eleições legislativas de 2002, ed. André Freire, Marina C. Lobo, and Pedro Magalhães, 87-124. Lisbon: Imprensa de Ciências Sociais.

Jalali, Carlos. 2007. Partidos e democracia em Portugal 1974-2005. Lisbon: Imprensa de Ciências Sociais.

Lafleur, Jean-Michel. 2012. Transnational politics and the state. The external voting rights of diasporas. Abingdon: Routledge.

Lafleur, Jean-Michel, and Marco Martiniello. 2009. Transnational political participation of immigrants. New York: Routledge.

Laver, Michael, and John Garry. 2000. Estimating policy positions from political texts. American Journal of Political Science 44: 619-634.

Laver, Michael, Kenneth Benoit, and John Garry. 2003. Extracting policy positions from political texts using words as data. American Political Science Review 97, 2: 311-331.

Lijphart, Arend. 1999. Patterns of democracy. New Haven: Yale University Press.

Lisi, Marco. 2010. The renewal of the socialist majority: The 2009 Portuguese legislative elections. West European Politics 33, 2: 381-388. 
Lobo, Marina C. 1996. A evolução do sistema partidário português à luz de mudanças económicas e políticas (1976-1991). Análise Social XXXI, 139: 1085-1116.

Lobo, Marina C. 2007. Portugal: Extended voting rights and decreasing participation. In Voting from abroad: The international IDEA handbook, AA. VV., 83-7. Stockholm: Trydells Tryckeri $\mathrm{AB}$.

López-Guerra, Claudio. 2006. Should expatriates vote? The Journal of Political Philosophy, 13, 2: 216-234

Malheiros, Jorge Macaísta, and Maria J. C. Boavida. 2003. El voto, arma del pueblo: La participación política de los emigrantes portugueses. In Votar en la distancia: La extensión de los derechos políticos a migrantes, experiencias comparadas, ed. Leticia Calderón Chelius, 457-488. Mexico: Instituto Mora.

Marcelli, Enrico, and Wayne A. Cornelius. 2005. Immigrant voting in home-country elections: Potential consequences of extending the franchise to expatriate Mexicans residing in the United States. Mexican Studies / Estudios Mexicanos 21, 2: 429-460.

Martins, Manuel Meirinho. 2004. Participação política e democracia: O caso português (1975-2000). Lisbon: Instituto Superior de Ciências Sociais e Políticas.

Nohlen, Dieter, and Florian Grotz. 2000. External voting: legal framework and overview of electoral legislation. Boletín Mexicano de Derecho Comparado XXXIII, 99: 1115-1145.

Norris, Pippa, ed. 1999. Critical citizens. Global support for democratic governance. Oxford Oxford University Press.

Nunes, Filipe. 2005. Eleições de segunda ordem em Portugal: O caso das europeias de 2004. Análise Social XL, 177: 795-813

Ostergaard-Nielsen, Eva, ed. 2003. International migration and sending countries: Perceptions, policies and transnational relations, Hampshire: Palgrave Macmillan.

Peixoto, João. 2004. País de emigração ou país de imigração? Mudança e continuidade no regime migratório em Portugal. Lisbon: SOCIUS Working Papers, 2.

Peixoto, João. 2007. Dinâmicas e regimes migratórios: O caso das migrações internacionais em Portugal. Análise Social XLII, 183: 445-369.

Pires, Rui Pena, ed. 2010. Portugal: Atlas das migrações internacionais. Lisbon: Tinta da China.

Reif, Karlheinz, and Hermann Schmitt. 1980. Nine second-order national elections: A conceptual framework for the analysis of European election results. European Journal of Political Research 8, 1: 3-44

Rubio-Marín, Ruth. 2006. Transnational politics and the democratic nation-state: Normative challenges of expatriate voting and nationality retention of emigrants. New York University Law Review 81: 117-147.

Santos, Vanda. 2004. O discurso oficial do estado sobre a emigração dos anos 60 a 80 e a imigração dos anos 90 à actualidade. Lisbon: ACIME.

Sassen, Saskia. 2007. A Sociology of Globalization. New York: W. W. Norton \& Company 
Spiro, Peter J. 2006. Perfecting political diaspora. New York University Law Review 81: 207-233.

Thompson, Judy. 2003. The implementation of external voting. In Voting from abroad: The international IDEA handbook, AA. VV., 113-127. Stockholm: Trydells Tryckeri AB.

Tintori, Guido. 2012. Il voto degli altri. Rappresentanza e scelte elettorali degli italiani all'estero. Turin: Rosenberg \& Sellier.

Vicente, António Luís. 1999. Os portugueses nos Estados Unidos da América: Política de comunidades e comunidade política. Lisbon: Fundação Luso-Americana para o Desenvolvimento.

Viegas, José Manuel Leite, and Sérgio Faria. 2004. A abstenção nas eleições legislativas de 2002. In Portugal a votos: As eleições legislativas de 2002, ed. André Freire, Marina C. Lobo, and Pedro Magalhães, 221-259. Lisbon: Imprensa de Ciências Sociais.

Viegas, José Manuel Leite, and Sérgio Faria. 2007. A abstenção eleitoral em Portugal: Uma perspectiva comparada. In Eleições e cultura política, ed. André Freire, Marina C. Lobo and Pedro Magalhães, 91-109. Lisbon: Imprensa de Ciências Sociais.

Volkens, Andrea. 2007. Strengths and weaknesses of approaches to measuring policy positions of parties. Electoral Studies 26: 108-120.

Yin, Robert. 2003. Case study research: Design and methods. Thousand Oaks: Sage.

\section{Party documents}

Bloco de Esquerda. 2009. A política socialista para Portugal. Programa para um governo que responda à urgência da crise social.

Centro Democrático e Social - Partido Popular. 2009. Programa Eleitoral.

Partido Comunista Português. 2009. Um compromisso com os trabalhadores, o povo e o país. Programa de ruptura, patriótico e de esquerda.

Partido da Nova Democracia. 2003. Uma ideia de Portugal.

Partido Social-Democrata. 2009. Compromisso de verdade. Programa eleitoral do Partido Social Democrata 2009/2013.

Partido Socialista. 2009. Avançar Portugal 2009-2013. Programa de governo do Partido Socialista.

\section{Press references}

Correio da Venezuela. 2009, September 5. Cavaco Silva veta [fim do] voto por correspondência. Retrieved October 29, 2009, from http://www.correiodevenezuela.com

Diário de Notícias. 2009, February 4. Veto de Cavaco mata lei do PS sobre voto emigrante. Retrieved April 20, 2012, from http://dn.sapo.pt

Diário Digital. 2009, May 22. Greve nos consulados não ameaça votação. Retrieved April 20, 2012, from http://diariodigital.sapo.pt 
Expresso. 2007, August 9. Reforma avança apesar de protesto dos emigrantes. Retrieved April 20, 2012, from http://aeiou.expresso.pt

Expresso. 2009, February 3. PS 'irá apreciar devidamente' razões de veto de Cavaco. Retrieved April 20, 2012, from http://aeiou.expresso.pt

IOL Diário. 2009, August 21. Ferreira Leite lamenta partido de 'jovens talentos'. Retrieved April 20, 2012, from http://diario.iol.pt

Jornal de Negócios. 2009, February 5. O voto dos emigrantes - por Marina Costa Lobo. Retrieved April 20, 2012, from http://www.jornaldenegocios.pt

LusoJornal - French Edition. 2007, March 8 (No. 110). 7.000 manifestantes contra o encerramento dos Consulados. Retrieved April 20, 2012, from http://www.lusojornal.com/

LusoJornal - French Edition, 2009, March 19 (No. 204). Manuela Ferreira Leite com militantes do PSD em Paris. Retrieved April 20, 2012, from http://www.lusojornal.com

Mundo Português. 2009, February 3. Lei eleitoral: Presidente da República veta fim do voto por correspondência dos emigrantes. Retrieved April 20, 2012, from http:// www.mundoportugues.org

Mundo Português. 2009, September 23. Trabalhadores consulares em greve dia 24. Retrieved April 20, 2012, from http://www.mundoportugues.org

TSF Rádio Notícias. 2009, February 3. Cavaco Silva veta fim do voto por correspondência dos emigrantes. Retrieved April 20, 2012, from http://tsf.sapo.pt

"This article draws on results from the research project "Voting Abroad: Political Participation and Citizenship of Portuguese Emigrants", conducted at the research center CIES-IUL (ISCTE-IUL) from September 2009 till December 2011. This project gathered a team of four researchers in political science and sociology with different academic affiliations. We thank the Emigration Observatory (Observatório da Emigração) for the financial and scientifc support. We are also extremely gratefu to the organizations and individuals who responded to our calls the Directorate General of Internal Administration (DGAI) and the National Elections Commission (CNE).

2 This group comprises Australia (1902), Norway (1921), France (1944), Iceland (1949), the USA (1955), Finland (1958), Colombia (1961), and Sweden (1968).

3 External voting was introduced only later in the election of the President of Republic (since 2001) and the European Parliament (since 2009; until then, participation was restricted to Portuguese nationals residing in another EU member state). Voter registration abroad is not mandatory, unlike the rule for citizens residing in Portugal. For a detailed discussion of the regulation, see Azevedo et al. (2012: 55-78).

4 For challenging debates on democracy and turnout, see Bobbio (1995), Norris (1999), or Lijphart (1999); on the particular case of Portugal, see Freire and Magalhães (2002) or Viegas and Faria (2004, 2007). 
5 This theory has been developed in the analysis of both party and voter behaviour. The underlying claim is that voters compare parties or candidates by measuring their competence in dealing with the issues that they - voters - consider most relevant. The interwoven impact of these considerations on electoral results appears to be confirmed by studies in several countries (Bélanger and Meguid, 2008: 477).

6 The content analysis of party manifestos was informed in particular by the comparison of approaches to measuring policy positions by Volkens (2007) and the codification system used in Laver and Garry (2000) and Budge et al. (2001).

7 On the importance of using multiple sources of evidence in case study research, see Yin (2003).

8 Interviews with at least one representative of the five parties represented in parliament was pursued through post, electronic mail and telephone calls; the only case in which this process was ultimately fruitless due to lack of reply from the party was the CDS-PP. Consulted public institutions were the Electoral Administration of the Directorate-General of Internal Administration (AE-DGAI), the National Comission for Elections (CNE), the Comission for the Registration of Portuguese Voter Abroad (COREPE), and the Council of Portuguese Communities (CCP).

9 LusoJornal - French Edition, 8/3/07; Expresso, 9/8/07

10 Diário Digital, 22/5/09; Mundo Português, 23/9/09.

11 See parliamentary debates of 19 September 2008, 16 January 2009, and 5 February 2009, available online (http://debates parlamento.pt); cf also Expresso, 3/2/09. TSF Rádio Notícias, 3/2/09. Mundo Português, 3/2/09; Diário de Notícias, 4/2/09; Correio da Venezuela, 5/2/09; Jornal de Negócios, $5 / 2 / 09$.

12 Further research is required to assess to what extent emigrant voters are able to distinguish orientations to action across parties, that is, if they associate given strategies with given parties. One of the interviewed members of the parliament suggested that emigrant voters do recognize different degrees of competence from parties to accomplish the propositions or deal with the problems mentioned during the campaign.

13 See Decree-Law 95C/76 from 30 January. During the campaign for the 2005 legislative elections, the National Commission for Elections (CNE, Process 20/05) received a complaint against the PS for public posters appealing to vote on street buses in Rio de Janeiro. PS representatives declared that they had neither responsibility nor knowledge of such action in Rio de Janeiro. The CNE advised greater caution to avoid similar incidents in the following elections.

14 LusoJornal - French Edition, 19/3/09; IOL Diário, 21/08/2009.

15 Official data from the parties at the time of electing their leaders provides an interesting contribution. The PS had about 830 fee-paying members abroad by 2006 , which corresponded to $1.4 \%$ of the total party affiliates. The PSD had 1360 members abroad in 2008 (417 in Europe and 943 outside Europe), i.e. $1,7 \%$ ot the total party affiliates. 